\title{
KARAKTERISTIK DAN FUNGSI QIRA’AH DALAM ERA LITERASI DIGITAL
}

\author{
Ahmad Nurcholis, Syaikhu Ihsan Hidayatullah, Muhamad Asngad Rudisunhaji \\ PBA IAIN Tulungagung, PBA IAIN Tulungagung, PBA IAIN Tulungagung \\ cholisahmad87@gmail.com, ihsansyaikhu@gmail.com, \\ asngadiainta75@gmail.com
}

\begin{abstract}
This article described and analyzed the characteristics of qira'ah and its functions in this digital literacy era. The need toward learning qira'ah (reading) by using computers and social media is high. The Arabic learning then adjust with Industrial Revolution 4.0 especially in learning qira'ah (reading). The use of Internet of Things (IoT), big data, cloud databases, block chain, and others will change the learning design of qira'ah from paper-based to paperless. The researchers use qualitative approach to produce the descriptive data. The results showed that the characteristics of qira'ah emphasize on the aspects of analysis and understanding of what is read, not on how to read. While the function of qira'ah in digital literacy era is the high quality of digital based literacy which is oriented not only on the religious field but also on academic, professional / practical, economic, and ideology.
\end{abstract}

Keywords: digital era, qira'ah, characteristics

\begin{abstract}
Abstrak:Artikel ini akan memaparkan dan menganalisis tentang karakteristik qira'ah serta fungsinya dalam era literasi digital. Kebutuhan pembelajaran qira'ah (membaca) pada computer dan media sosial saat ini sangatlah tinggi. Dunia pembelajaran bahasa Arab tengah memasuki revolusi digital atau industrialisasi keempat khusunya pembelajaran qira'ah (membaca). Penggunaan Internet of Things (IoT), big data, cloud database, blockchain, dan lain-lain akan mengubah pola pembelajaran qira'ah dari paper based menuju paperless. Penulis menggunakan pendekatan kualitatif untuk menghasilkan data deskriptif. Hasil temuan penelitian bahwa karakteristik qira'ah dalam era literasi digital menekankan pada aspek analisis dan pemahaman terhadap apa yang dibaca, bukan pada cara membaca. Sedangkan fungsi qira'ah dalam era literasi digital adalah meningkatnya kualitas literasi yang berbasis digital yang berorientasi tidak hanya pada bidang religius tetapi juga akademis, profesional/praktis, ekonomis dan ideologis.
\end{abstract}

Kata-kata kunci: era digital, qira'ah, karakteristik 


\section{A. Pendahuluan}

Empat keterampilan dalam pembelajaran bahasa Arab sebagai bahasa asing mencakup, yakni maharah istima', maharah kalam, maharah qira'ah dan maharah kitabah. ${ }^{1}$ Pada dasarnya kalam memang merupakan inti dari bahasa. Namun, qira'ah adalah salah satu kunci pembelajaran kalam. Sedangkan kitabah merupakan gambaran dan simbol dari kalam. Pembelajaran bahasa Arab sebagai bahasa asing menuntut fase qira'ah dan kitabah lebih dahulu sebagai pondasi awal memasuki fase kalam. ${ }^{2}$ Jadi, qira'ah adalah kunci pembelajaran Bahasa Arab terutama untuk pebelajar Bahasa Arab sebagai bahasa asing."

Namun pada faktanya, membaca teks Arab tidaklah mudah. Dalam beberapa pengamatan dan penelitian pembelajaran bahasa Arab, banyak siswa yang sudah lulus dari sekolah masih mengalami kesulitan dalam membaca teks Arab baik dari buku, koran, majalah, web Arab, atau literatur Arab lainnya. Demikian halnya tidak jarang siswa dalam proses belajar di sekolah merasa kesulitan saat menghadapi teks-teks Arab yang terdapat di buku paket dan LKS. Hal ini dibuktikan dengan hasil belajar mereka di bidang maharah qira'ah yang mengalami fluktuasi bahkan gradasi.

Ada beberapa faktor yang mempengaruhi kurang maksimalnya hasil belajar siswa dalam maharah qira'ah. Di antara faktor tersebut adalah kelemahan dari segi perencanaan tujuan, metode, materi, media, dan evaluasi. Dari faktor-faktor tersebut, yang sangat berpengaruh adalah dari segi metode. Lemahnya guru dalam menguasai metode sangat berpengaruh terhadap jalannya pembelajaran. Metode yang kurang menarik akan melemahkan daya motivasi siswa yang juga akan mengakibatkan menurunnya tingkat ketercapaian tujuan materi qira’ah itu sendiri. Bahka ada yang mengatakan bahwa "At-Thariqatu ahammu minal madah" atau metode lebih penting daripada materi.

Namun, sebelum menentukan metode yang akan digunakan dalam pembelajaran, alangkah baiknya guru memahami betul tentang materi yang akan disampaikannya. Dalam hal ini terkhusus pada materi qira'ah. Bagaimana karakter qira’ah, macam-macam qira'ah, dan tujuan-tujuan qira’ah. Dengan demikian guru akan mampu menyinkronkan antara metode dan materi (pelajaran) secara tepat dan proporsional.

Tantangan pembelajaran qira'ah dalam era literasi digital adalah karena sampai sekarang guru masih banyak memakai produk 80-an, sementara muridnya sudah memakai produk kontemporer. Sehingga pembelajaran qira'ah dalam era literasi digital dalam mempublikasikan qiraah sebagai materi ajar dituntut lebih maju yaitu

1 Muhammad Hadi Masruri, Al-Hujum Majallat 'Arabiyyah Amaliyyah li al-Tsaqafah al-Islamiyyah, (Malang: Jami'ah Islamiyyah Malang, 2006), h. 2

2 Ali al-Hadidiy, Musykilat Ta'liim al-Lughah al-Arabiyyah li ghairil 'Arab, (Kairo: Dar al-Katib alArab, t.t), h. 150

3 Umar Faruq, "Tathbiq Thariqah al-Qira'ah al-Muatsafah fi Ta'liim an-Nushush al-Adabiyyah (bit Tathbiq 'ala Thalabah Jami'ah Kediri al-Islamiyyah al-Hukumiyyah)" dalam jurnal at-Tadris, vol. 2, (Tulungagung: IAIN Tulungagung, 2014), h. 224 
dengan menggunakan teknologi literasi digital. Era literasi digital ini tidak dapat menggeser posisi guru akan tetapi guru yang tidak dapat menguasi teknologi literasi digital akan tergeser dengan sendirinya.

Oleh karena itu dalam penelitian ini, penulis menyajikan beberapa subbab tentang pelajaran qira'ah yang terdiri dari karakter dan unsur-unsur qira'ah, pengembangan konsep qira'ah, maharah qira'ah, fungsi qira'ah, tujuan qira'ah dan macam-macam qira'ah serta definisi literasi digital dan unsur-unsur yang mempengaruhi pembelajaran qira'ah dalam era literasi digital.

\section{B. Landasan Teori \\ 1. Maharah Qira'ah}

Secara etimologi, kata maharah dalam kamus Lisan al-Araby dinyatakan "AlMaahir: As-Saabih" kemudian disebutkan sebuah kalimat "maharta bi hadza al-amri amhar bihi maharah: ay sharat bihi haadziqan". ${ }^{4}$ Berdasarkan pengertian etimologi ini, maka dapat dipahami bahwa makna maharah secara bahasa berkaitan dengan ketelitian, keterampilan, dan kecakapan terhadap sesuatu.

Adapun keterampilan membaca (maharah al-qira'ah/ reading skill) menurut Hermawan adalah kemampuan mengenali dan memahami isi apa yang tertulis (lambang-lambang tertulis) dengan melafalkan atau mencernanya di dalam hati. ${ }^{5}$

Didukung pula oleh Effendy yang mengatakan bahwa kemahiran membaca mengandung dua aspek atau pengertian. Pertama, perubahan lambang tulis menjadi bunyi. Kedua, menangkap arti dari seluruh situasi yang dilambangkan melalui lambang-lambang tulis dan bunyi tersebut. ${ }^{6}$

Inti dari kemahiran membaca terletak pada aspek yang kedua. Ini tidak berarti bahwa kemahiran dalam aspek pertama tidak penting, sebab kemahiran dalam aspek yang pertama adalah dasar dari kemahiran yang kedua. Betapapun juga, keduanya merupakan tujuan yang hendak dicapai oleh pengajaran bahasa. ${ }^{7}$

\section{Macam-Macam Qira'ah}

\section{a. Macam-Macam Qira'ah Dari Segi Tujuan Pembaca/Qari'}

\section{Membaca Cepat}

Tujuan utama membaca cepat adalah untuk menggalakkan siswa agar berani membaca lebih cepat daripada biasanya. Kecepatan menjadi tujuan tetapi tidak boleh mengesampingkan pengertian. ${ }^{8}$ Dalam membaca cepat,

\footnotetext{
4 Ibn Mandzur, Lisan Al-Arab, cet. 5, (Beirut: Dar Shadir, 1300 H), h. 185

5 Acep Hermawan, Metodologi..., h. 100

6 Ahmad Fuad Effendy, Metodologi Pengajaran Bahasa Arab, (Malang: Misykat, 2005), h. 127

7 Ibid.

8 Mustofa, Strategi Pembelajaran..., h. 171
} 
siswa tidak diminta memahami rincian-incian isi, tetapi cukup dengan pokok-pokoknya saja. Namun, perlu diingat bahwa tidak setiap bahan bacaan bias digunakan sebagai bahan membaca cepat. ${ }^{9}$

Para ahli berpendapat bahwa membaca cepat tidak hanya memperbaiki prestasi waktu, tetapi menambah banyaknya informasi yang dapat diserap oleh pembaca. Ini dimungkinkan karena pembaca tidak lagi mempunyai kebiasaan membaca kata demi kata, tetapi ia dapat menggerakkan matanya dengan pola-pola tertentu, sehingga pesan dari teks dapat ditangkap dengan cepat dan sangat efisien masalah waktu. ${ }^{10}$

2. Membaca untuk Membentuk Generalisasi dari Tema Luas

Membaca jenis ini seperti membaca Undang-Undang atau membaca buku baru. Membaca jenis ini dimaksudkan untuk memperkaya pengetahuan yang memang seharusnya dibaca oleh manusia di zaman modern ini yang dapat meningkatkan produktivitas akal pikiran. Membaca jenis ini berbeda dengan membaca pada situasi dan tempat-tempat khusus. Tujuan dari qira'ah ini adalah untuk mendapatkan data-data informasi dengan cepat disertai pemahaman arti yang luas mencakup informasi di berbagai daerah lain. ${ }^{11}$

3. Membaca untuk Pemahaman

Maksud dari membaca jenis ini adalah untuk mendalami. Membaca jeni ini dilakukan dengan pelan-pelan dan hati-hati. Tujuannya adalah untuk memahami persoalan secara global maupun secara rinci. Juga untuk mempertimbangkan pengetahuan-pengetahuan yang memiliki kesamaan atau perbedaan dan lain sebagainya. ${ }^{12}$

4. Membaca untuk Mengumpulkan Pengetahuan

Dalam membaca jenis ini, pembaca merujuk kepada sejumlah sumbersumber dan mengumpulkan pengetahuan khusus yang dibutuhkan. Membaca jenis ini seperti membaca yang digunakan sebagai penelitian, makalah, tesis dan sebagainya. ${ }^{13}$

9 Fathul Mujib dan Nailur Rahmawati, Permainan Edukatif Pendukung Pembelajaran Bahasa Arab, (Yogyakarta: Diva Press, 2012), h. 64

10 Mustofa, Strategi Pembelajaran..., h. 171

11 Ibrahim, Al-Muwajjih Al-Fanny..., h. 73

12 Ibrahim, Al-Muwajjih Al-Fanny..., h. 73

13 Ibid. 
5. Membaca untuk Menikmati Sastra dan Senam Otak

Yaitu membaca yang tidak mendalam dan tidak melibatkan pemikiran. Seperti membaca naskah sastra, anekdot dan sebagainya. ${ }^{14}$

6. Membaca Kritis Analitis

Tujuan utamanya ialah untuk melatih siswa agar memiliki kemampuan mencari informasi dari bahan tertulis. Siswa dilatih agar dapat menggali dan menunjukkan detail-detail yang memperkuat ide utama yang ingin disampaikan oleh penulis. ${ }^{15}$ Siswa juga dilatih berpikir secara logis, mencari hubungan antara satu kejadian dengan kejadian yang lain, dan menarik kesimpulan dalam naskah teks yang ada. ${ }^{16}$ Membaca seperti ini dapat berbentuk mengkritisi buku, membandingkan antara buku yang satu dengan buku yang lain dan sebagainya. ${ }^{17}$

\section{b. Macam-Macam Qira'ah dari Segi Kesiapan Mental}

a. Membaca untuk Pelajaran

Membaca jenis ini berkaitan dengan tuntutan profesi, tugas-tugas warga negara, dan sebagainya dari macam-macam aktivitas kehidupan. Tujuannya adalah aplikasi atas proses pencarian pengetahuan dan datadata. ${ }^{18}$

b. Membaca untuk rekreatif

Tujuan membaca rekreatif bukanlah untuk menambah jumlah kosakata, bukan untuk mengajarkan pola-pola baru, bukan pula untuk pemahaman teks bacaan secara rinci, tetapi untuk memberikan latihan kepada para siswa membaca cepat serta menyenangkan. ${ }^{19}$ Tujuannya yang lebih jauh adalah untuk membina minat dan kecintaan siswa dalam membaca. ${ }^{20}$

Bahan bacaan yang menjadi pilihan hendaknya bacaan yang ringan dan popular serta sekiranya siswa tertarik dengan isi bacaannya, baik ditinjau dari segi isi maupun susunan bahasanya. Biasanya berupa cerita pendek atau novel yang telah dipermudah bahasanya sesuai dengan tingkatan pemahaman siswa yang menjadi sasarannya. ${ }^{21}$

Membaca cepat maupun rekreatif, biasanya dilakukan di luar kelas, dengan cara penugasan kepada siswa untuk membaca buku tertentu, dan dengan waktu

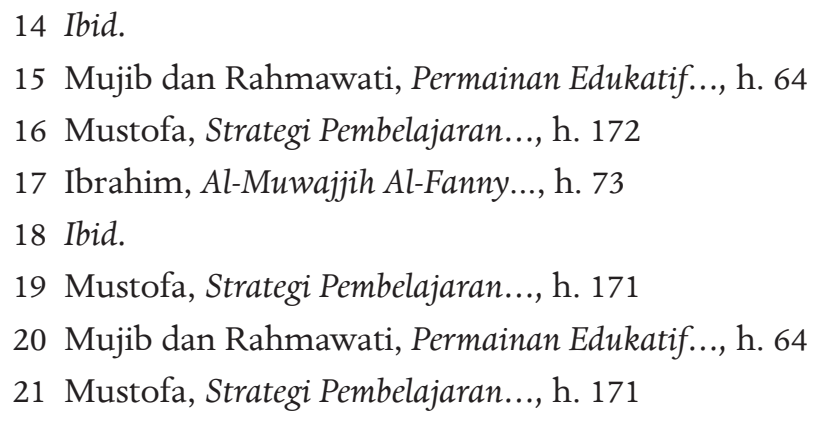


yang terbatas siswa harus menyerahkan laporan tertulis tentang buku yang telah dibacanya, agar semua kegiatan terekam dengan baik. ${ }^{22}$

\section{c. Macam-Macam Qira'ah Lain}

Ada pula yang menyebutkan macam qira'ah selain yang sudah dipaparkan di atas. Namun, tidak ada keterangan mengenai pembagiannya ditinjau dari sudut apa. Yaitu membaca intensif dan (Al-Qira'ah Al-Mukatsafah) membaca ekstensif (AlQira'ah Al-Muwassa'ah/At-Takmiliyah).

\section{a. Membaca Intensif (Al-Qira'ah Al-Mukatsafah)}

Terminologi membaca intensif adalah membaca yang digunakan sebagai sarana pembelajaran kata-kata dan gramatika baru. ${ }^{23}$ "Telaah kata-kata, dikte dan diskusi umum adalah parsial dan teknik intensif”. ${ }^{24}$ Sedangkan teks-teks bacaan yang benarbenar sesuai dengan maksud jenis membaca intensif diseleksi oleh pendidik, baik dari aspek format maupun dari aspek konten (isi) nya. Adapun tujuan utama dari membaca intensif adalah untuk mendapatkan pemahaman yang sempurna beserta simbolnya, nada-nada tambahan yang bersifat emosional dan sosial, format sikap dan tujuan si pengarang, di samping medium linguistik yang dipergunakan untuk merealisasikan tujuan. ${ }^{25}$

Dari tujuan ini dapat disimpulkan bahwa membaca intensif hendaknya dibiasakan secara kontinyu, yang setiap harinya minimal empat halaman, dimulai dengan membaca teks-teks pendek. Di samping itu, dalam membaca intensif ini ada beberapa faktor yang harus berpartisipasi aktif, yaitu: kejelasan teks bacaan, pengenalan pembaca terhadap isi bacaan. Sebab kita akan lebih mudah memahami bacaan yang telah kita akrabi. Mengacu kepada tujuan ini, maka akan dipaparkan berikut teknik pembelajaran keterampilan membaca intensif (Al-Qira'ah AlMukatsafah) secara rinci. ${ }^{26}$

1. Pendidik mempersiapkan nuansa teks pendek yang telah dipilih. Panjang teks tersebut kira-kira dua sampai empat lembar (halaman).

2. Teks yang disediakan pendidik tentunya berisikan kata-kata dan pola kalimat baru.

3. Sebaiknya aktivitas ini dilaksanakan dalam kelas

4. Kemudian pendidik meminta peserta didiknya agar membaca bahan (teks) tersebut secara teliti dan seksama. Waktu yang dibutuhkan kira-kira dua

\section{Ibid., h. 172}

23 Al-Khuuli, Asaaliibu Tadrisi..., h. 113

24 Tarigan, Membaca sebagai..., h. 35

25 Ibid., h. 36

26 Zulhannan, Teknik Pembelajaran..., h. 103 
menit dari teks yang panjangnya lima ratus patah kata. Jadi kecepatan membaca kurang lebih lima patah kata dalam satu detik. ${ }^{27}$

b. Membaca Ekstensif (Al-Qira'ah Al-Muwassa'ah/ At-Takmiliyah)

Terminologi membaca ekstensif adalah jenis membaca yang mempunyai sifat lebih luas dan menyeluruh (komprehensif), yaitu mencakup bacaan panjang maupun pendek. ${ }^{28}$ Sedangkan membaca ekstensif ini memiliki tujuan tertentu, yang secara teoritis memperjelas teknis pembelajarannya. Adapun tujuan utama keterampilan membaca ekstensif adalah memotivasi siswa serta membangkitkan semangat dari apa yang telah dipelajarinya, baik itu berupa kosakata maupun pola kalimat yang diajarkan saat melakukan bacaan intensif. ${ }^{29}$ Dari tujuan ini dapat dipahami bahwa membaca ekstensif lebih komprehensif, membutuhkan ketelitian dan analisis yang tajam serta tenaga ekstra di dalam mengkaji nuansa teks bacaan yang disajikan.

Sektor lain, yang perlu dikaji dan dianalisis adalah perbedaan membaca ekstensif dan membaca intensif.

1. Teks bacaan membutuhkan ketelitian dan analisis tajam, di samping penuh seksama.

2. Materi yang disajikan sesuai dengan stratifikasi peserta didik, dan diperbolehkan membaca di rumah masing-masing

3. Nuansa teks yang disajikan, mayoritas panjang-panjang

4. Teknis penyajiannya bisa direalisasikan dengan cara berdiskusi

5. Penyajian membaca ekstensif ini lebih sesuai untuk peserta didik tingkat intermediate dan advanced. ${ }^{30}$

Teknik pembelajaran keterampilan membaca ekstensif ini pada prinsipnya sama dengan teknik pembelajaran membaca intensif, sehingga di sini tidak perlu dipaparkan ulang.

\section{Literasi Digital}

Istilah literasi digital mulai popular sekitar tahun 2005. Literasi digital bermakna kemampuan untuk berhubungan dengan informasi hipertekstual dalam arti bacaan tak berurut yang dibantu komputer. Kemudian Gilster memperluas konsep literasi digital sebagai kemampuan memahami dan menggunakan informasi dari berbagai sumber digital, dengan kata lain kemampuan untuk membaca, menulis dan berhubungan dengan informasi dengan menggunakan teknologi dan format yang ada pada masanya.

\footnotetext{
27 Ibid., h. 104

28 Ibid.

29 Al-Khuulii, Asaaliibu Tadris..., h. 113

30 Zulhannan, Teknik Pembelajaran..., h. 104
} 
Definisi lain dari istilah literasi digital sering digunakan untuk menunjukkan konsep yang luas yang menautkan bersama-sama berbagai literasi yang sesuai serta literasi berbasis kompetensi dan keterampilan teknologi komunikasi, namun menekankan pada kemampuan evaluasi informasi yanglebih "lunak" dan perangkaian pengetahuan bersama-sama pemahaman dan sikap.

IFLA ALP Workshop pada tahun 2006 menyebutkan bagian dari literasi informasi adalah literasi digital, yang diartikan sebagai kemampuan memahami dan menggunakan informasi dalam berbagai format dari sejumlah besar sumber daya tatkala sumber daya tersebut disajikan melalui komputer. Sesuai perkembangan internet, maka pemakai tidak mencari tahu darimana asalnya informasi, yang penting ialah dapat mengaksesnya.

Literasi digital mencakup pemahaman tentang Web dan mesin pencari. Pemakai memahami bahwa tidak semua informasi yang tersedia di Web memiliki kualitas yang sama. Dengan demikian pemakai lambat laun dapat mengenali situs Web mana yang handal dan situs mana yang tidak dapat dipercayai. Dalam literasi digital ini pemakai dapat memilih mesin pemakai yang baik sesuai keinginan, dan mampu menggunakan mesin pencari secara efektif (misalnya dengan "advanced search").

Jadi dari definisi tersebut dapat disimpulkan literasi digital adalah himpunan sikap, pemahaman, dan keterampilan menangani dan mengkomunikasikan informasi dan pengetahuan secara efektif dalam berbagai media dan format.

\section{Metode Penelitian}

Penelitian ini termasuk dalam jenis penelitian lapangan (field research) yang berorientasi pada deskripsi secara umum (descriptive study) dengan menggunakan pendekatan kualitatif untuk menghasilkan data deskriptif berupa kata-kata tertulis dan lisan dari berbagai sumber informasi yang dibutuhkan. Penelitian ini berusaha untuk melihat, mengamati, dan mengetahui keadaan sebenarnya serta menggali informasi melalui teknik-teknik pengamatan (observasi), wawancara mendalam, wawancara informal dan diskusi kelompok (focus group discussion).

Berdasarkan jenis-jenis data yang diperlukan, maka dalam penelitian ini, sumber data yang digunakan melalui field research yaitu sumber data yang diperoleh dari lapangan penelitian, yaitu mengamati fenomena yang terjadi di dunia pendidikan pada era literasi digital ini. Analisis yang dilakukan dalam penelitian ini adalah analisis mendalam dalam rangka mencari temuan-temuan yang valid, yang digambarkan Spradley berikut:

a. Proses reduksi data, peneliti melakukan pemilahan, memfokuskan pada data yang mengarah untuk pemecahan masalah, penemuan, pemaknaan dan menjawab pertanyaan penelitian, kemudian menyederhanakan, menyusun secara sistematis dengan menonjolkan hal-hal yang dipandang penting sebagai hasil temuan. 
b. Hasil reduksi kemudian disajikan dalam bentuk display data, menggunakan uraian (teks naratif).

\section{Pembahasan}

\section{Karakter Qira'ah dan Unsur-Unsurnya}

Qira'ah adalah suatu proses sinkronisasi hubungan antara bahasa verbal dan simbol-simbol tertulis (non verbal). Bahasa verbal terbentuk dari makna-makna dan kata-kata yang membentuk makna-makna tersebut. Dari sini dapat dipahami bahwa unsur-unsur qira'ah ada tiga, yaitu: makna yang abstrak, kata yang membentuk makna, dan simbol yang tertulis. ${ }^{31}$

Tugas dari pembelajaran adalah penyusunan antara ketiga unsur tersebut. Simbol yang telah berpindah ke dalam bahasa verbal (ujaran) disebut dengan qira'ah. Adapun proses sebaliknya disebut kitabah (menulis). Penerjemahan simbol menjadi makna-makna disebut qira'ah sirri. Adapun penerjemahan menjadi lafadz-lafadz yang dapat didengar disebut qira'ah jahriyyah (nyaring). ${ }^{32}$

Di samping itu, ada karakter lain dari qira'ah yang perlu dipahami. Goodman dalam Thu'aimah mengatakan bahwa qira'ah dari sisi sifatnya adalah termasuk proses reseptif. ${ }^{33}$ Qira'ah memiliki karakter konsumtif atau menerima (reseptive skill). Sedangkan kitabah (menulis) memiliki karakter produktif (productive skill). Qira'ah mempunyai kesamaan dengan istima' yaitu sebagai keterampilan reseptif. ${ }^{34}$

\section{a. Pengembangan Konsep Qira'ah}

Konsep qira'ah telah mengalami perkembangan yang cukup panjang. Di bawah ini adalah beberapa pengembangan konsep qira'ah dalam pandangan Ibrahim melalui bukunya Al-Muwajjih Al-Fanny li Mudarrisiy Al-Lughah Al-Arabiyyah:

1. Konsep qira'ah hanya terbatas pada ruang yang sempit. Batasannya adalah terkait simbol tertulis secara visual, mengidentifikasinya dan mengucapkannya. Pembaca yang baik adalah yang mampu melafalkan (menyampaikan) dengan baik.

2. Konsep tersebut kemudian berubah sebagai hasil dari penelitian-penelitian dalam bidang pendidikan. Sehingga konsep qira'ah menjadi proses kerja akal pikiran, yang kemudian menimbulkan suatu kepahaman. Maksudnya adalah penerjemahan simbol-simbol ke dalam maksud dari ide yang ingin disampaikan. Sehingga membaca tidak hanya terpaku kepada kegiatan

31 Abdul Alim Ibrahim, Al-Muwajjih Al-Fanny li Mudarrisiy Al-Lughah Al-Arabiyyah, (Kairo: Dar Al-Ma'arif, 1968), h. 57

32 Ibid.

33 Rusydi Ahmad Thu'aimah, al-Maharaat al-Lughawiyyah Mustawiyatuha, (Kairo: Dar al-Fikr al'Arabiy, 2004), h. 187

34 Thaha Ali Husain dan Sa'ad Abdul Karim al-Waili, Ittajahaat Hadiitsah fi Tadris al-Lughah alArabiyyah, (Yordania: Jidar lilkutub al-Alamy, 2009), H. 8 
melafalkan tetapi juga memahami makna bacaan secara baik yang melibatkan unsur kognitif maupun psikomotorik.

3. Kemudian konsep qira'ah berkembang lagi dengan menambahkan unsur lain yaitu meliputi penjiwaan pembaca atas isi bacaan. Jadi pembaca yang baik adalah pembaca yang mampu melakukan komunikasi secara erat dengan bacaan, ia bisa gembira, marah, kagum, rindu, sedih, dan sebagainya sesuai gelombang isi bacaan.

a. Unsur-Unsur yang Mempengaruhi Pembelajaran Qiraah dalam Era Literasi Digital

Menurut Bawden, unsur-unsur literasi digital yang dapat mempengaruhi pembelajaran qira'ah terdiri dari empat bagian sebagai berikut :

1. Tonggak pendukung berupa literasi itu sendiri dan literasi komputer, informasi, dan teknologi komunikasi.

2. Pengetahuan latar belakang terbagi atasdunia informasi dan sifat sumber daya informasi.

3. Kompetensi berupa:
a. pemahaman format digital dan nondigital
b. penciptaan dan komunikasi informasi digital
c. evaluasi informasi
d. perakitan pengetahuan
e. literasi informasi
f. literasi media

c. Sikap dan perspektif.

Merupakan proses menciptakan tautan antara konsep baru literasi digital dengan gagasan lama tentang literasi. Perseorangan harus memiliki kemampuan dan kompetensi yang berlandaskan kerangka kerja moral, yang diasosiasikan dengan seseorang yang terdidik. Dari semua komponen literasi digital, mungkin yang paling sulit diajarkan adalah kerangka kerja moral, namun hal itu paling mendekati dengan istilah informasi.

\section{Karakteristik Qira'ah dalam Era Literasi Digital}

Berdasarkan pembahasan di atas, dapat penulis analisis bahwa qira'ah (membaca) bukanlah proses sederhana. Konsep qira'ah (membaca) mengalami perkembangan. Pengembangan konsep qira'ah ini disebabkan oleh semakin perhatiannya para pakar pendidikan dalam mengkaji bidang qira'ah. Pada dasarnya qira'ah terdiri dari tiga 
unsur yaitu makna, kata yang membawakan makna dan simbol yang tertulis. Ketiga unsur ini saling berhubungan satu sama lain.

Secara ringkas qira'ah adalah proses yang menghendaki adanya hubungan antara bahasa verbal dan simbol-simbol tertulis (non verbal) dimana bahasa verbal terbentuk dari makna-makna dan kata-kata yang membawakan makna-makna tersebut. Karakter qira'ah yang lain dapat dilihat dari segi sifatnya yaitu merupakan proses reseptif. Qira'ah memiliki karakter konsumtif atau menerima (reseptive skill). Dia kebalikan dari kitabah (menulis) yang memiliki karakter produktif (productive skill). Qira'ah memiliki kesamaan dengan istima' sebagai keterampilan reseptif.

Sehingga -menurut penulis- sangatlah wajar jika terdapat perbedaan pendapat mengenai klasifikasi istima' yang dimasukkan ke dalam macam-macam atau jenis-jenis qira'ah. Hal ini sebenarnya bukan persoalan yang esensial. Karena semua tergantung pada pijakan teori masing-masing. Senyampang mampu berdiri pada landasan teori yang kuat, maka suatu pendapat akan dapat diterima. Namun, pada kesempatan ini penulis lebih cenderung sependapat dengan golongan yang mengatakan bahwa istima' tidak termasuk pada macam-macam qira’ah.

Mengenai pengembangan konsep qira'ah, berawal dari konsep pertama bahwa dahulu para pelajar pergi ke sekolah dengan tujuan untuk belajar membaca. Dari pengertian ini, membaca dianggap sebagai tujuan utama. Bahwa sekolah semata-mata hanya untuk belajar membaca. Kemudian semakin kesini semakin berkembang bahwa membaca diposisikan sebagai proses kerja akal pikiran, yang kemudian melahirkan kepahaman. Maksudnya adalah penerjemahan simbol-simbol ke dalam maksud dari ide yang dikehendaki. Sehingga membaca tidak hanya terpaku kepada kegiatan melafalkan tetapi juga memahami makna bacaan dengan baik yang melibatkan unsur kognitif dan psikomotorik.

Kemudian konsep qira'ah berkembang lagi dengan menambahkan unsur lain yaitu menyangut penjiwaan pembaca atas isi bacaan. Jadi pembaca yang baik adalah pembaca yang mampu berkomunikasi secara erat dengan bacaan, ia bisa gembira, marah, kagum, rindu, sedih, dan sebagainya sesuai gelombang isi bacaan.

Konsep qira'ah yang terakhir lebih luas lagi, bahwa membaca bukan hanya seperti yang dijelaskan di atas, tetapi menggunakan isi bacaan itu dalam kehidupan sehari-hari. Jadi pembaca yang baik adalah orang yang menggunakan isi bacaan dalam kehidupannya.

Dari pengembangan di atas, penulis meringkas menjadi semula qira'ah sebagai tujuan (dalam artian pelafalan), kemudian bertambah untuk pemahaman, lalu penjiwaan dan terakhir adalah aplikasi dalam kehidupan sehari-hari. Dari empat tahap perkembangan di atas, -agaknya- hanya dua yang kini menjadi titik konsentrasi para pembelajar khususnya pembelajaran bahasa Arab sebagai bahasa asing. Yaitu membaca dalam kaitan pelafalan dan pemahaman. 
Dalam kaitan penjiwaan dan aplikasi merupakan hal yang "sunnah". Karena bahasa Arab sebagai bahasa asing terutama bagi penutur non Arab (Indonesia) yang terbiasa dengan tulisan Latin tentu bukan perkara yang mudah. Butuh kerja keras untuk dapat sampai pada tahap pemahaman. Bahkan, dalam beberapa kesempatan ada yang masig mengalami problematika di bidang pelafalan. Karena tulisan bahasa Arab sangat jauh berbeda dengan tulisan Latin. Ada karakteristik khusus dalam bahasa Arab. Problem tersebut dapat muncul dari segi linguistik seperti fonologi, morfologi, sintaksis (nahwu dan sharaf) juga dapat muncul dari segi non linguistik.

Dalam usaha memahami membutuhkan proses kerja akal yang kompleks. Untuk sampai pada tingkat pemahaman, peserta didik membutuhkan penguasaan gramatika yang baik. Oleh karena itu, pembatasan konsep yang -menurut penulisproporsional bagi penutur non Arab seperti Indonesia adalah sampai pada tingkat pelafalan dan pemahaman.

\section{Fungsi Qiraah}

Dunia sekarang adalah dunia literasi. Dunia membaca dan menulis. Dua hal ini merupaka cermin dari perkembangan peradaban dunia. Bahkan dapat dikatakan kemajuan suatu negara dapat diukur dari seberapa tinggi kualitas literasi masyarakatnya. Apalagi sekarang diiringi dengan teknologi modern dan alat-alat komunikasi yang canggih. Dunia seakan dalam genggaman. Maka qira'ah khususnya bahasa Arab harus semakin ditingkatkan, karena orientasi bahasa Arab semakin meluas. Tidak hanya untuk religius tetapi juga akademis, profesional/ praktis, ekonomis dan ideologis.

Pembelajaran qira'ah memiliki banyak tujuan, di antaranya yang paling penting menurut Thu'aimah adalah:

a. Tercapainya penguasaan keterampilan membaca dengan baik

b. Membaca adalah aktivitas penting dalam pendidikan yang tidak dapat ditinggalkan. Dengan mahir membaca siswa dapat lebih mampu menyerap referensi bahasa asing lebih cepat dan akurat.

c. Masyarakat modern sering menggunakan kemampuan membaca dalam menjalankan tugas-tugasnya.

d. Membaca dapat menambah wawasan di segala bidang.

e. Memenuhi tujuan pengajaran bahasa Arab, agar siswa terampil dalam membaca. ${ }^{35}$

Berikut ini ada dua tujuan keterampilan membaca menurut Mustofa, yaitu tujuan umum dan tujuan khusus. Tujuan umum dari pembelajaran keterampilan membaca yaitu:

35 Rusydi Ahmad Thu'aimah, Ta'lim Al-Aarabiyya Lighairi Al-Nathiqi biha: Manahijuhu wa Asalibuhu, (Mesir: Jami’ah al-Manshurah, 1989), h. 175-176 

a. Mengenali naskah tulisan suatu bahasa
b. Memaknai dan menggunakan kosakata asing
c. Memahami informasi yang dinyatakan secara eksplisit dan implisit
d. Memahami makna konseptual
e. Memahami nilai komunikatif dari satu kalimat
f. Memahami hubungan dalam kalimat, antar kalimat, antar paragraf
g. Menginterpretasi bacaan
h. Mengidentifikasi informasi penting yang ada dalam wacana
i. Membedakan antara gagasan utama dengan gagasan penunjang
j. Menentukan hal-hal penting untuk dijadikan rangkuman. ${ }^{36}$

\section{Fungsi Qira'ah dalam Era Literasi Digital}
a. Dalam kehidupan individu ${ }^{37}$

1. Dahulu, anak-anak pergi ke sekolahan dan belajar agar bisa "membaca". Hal ini menunjukkan bahwa qira'ah adalah "tujuan” yang diharapkan. Kemudian ide ini berkembang setelah adanya sejumlah penlitian di bidang pendidikan. Sehingga tujuan pendidikan adalah anak pergi ke sekolahan kemudian membaca untuk belajar. Dalam hal ini, qira'ah menjadi sarana dalam proses pengetahuan dan menambah pengalaman. Jadi, dapat ditarik kesimpulan bahwa "dahulu, anak belajar agar bisa membaca, kini bergeser anak membaca untuk belajar”.

2. Membaca adalah proses kontinuitas bagi individu. dilakukan saat di sekolahan ataupun di luar sekolahan. Membaca adalah proses seumur hidup. Dengan demikian, membaca berbeda dengan materi-materi pelajaran lainnya. Boleh jadi membaca adalah keterampilan yang mengambil bagian terbesar dalam kehidupan manusia.

3. Dunia sekarang adalah dunia membaca dan pengetahuan. Meskipun telah tersebar sarana-sarana produk peradaban di zaman modern ini seperti radio, televisi, namun qira'ah tetap memiliki keunggulan dibanding produk-produk tersebut. Qira'ah unggul dari segi kemudahan, kecepatan, kebebasan, tidak adanya batas waktu tertentu, atau batasan tempat tertentu. 
4. Qira'ah adalah sarana untuk berkomunikasi antara individu satu dengan yang lainnya.

5. Qira'ah adalah dasar dari setiap proses pembelajaran dan kunci untuk semua materi pelajaran. Ada kemungkinan kelemahan dalam qira'ah adalah penyebab kegagalannya dalam materi-materi lain atau bahkan menjadi sebab kegagalannya dalam hidup.

6. Qira'ah membekali setiap individu dalam hal ide-ide dan pengetahuan.

b. Dalam hidup bermasyarakat ${ }^{38}$

1. Qira'ah adalah sarana yang tepat untuk kesadaran bermasyarakat, menghubungkan antara satu dengan yang lain melalui jurnalistik, surat menyurat, kepengarangan, kritik, arahan, dan lain sebagainya yang tertulis mewakili ucapan.

2. Qira'ah adalah sarana terpenting yang mengajak pada kepahaman dan kedekatan antara elemen-elemen masyarakat.

3. Qira'ah memiliki peran yang urgen dalam mengatur masyarakat.

4. Qira'ah dalam masyarakat dapat diserupakan kawat berduri listrik yang menyusun bangunannya. Dimana arus akan mengisi kawat hingga menghasilkan cahaya. Sebagaimana orang-orang yang lemah qira'ah diibaratkan seperti sebidang tanah yang tidak siap untuk menyampaikan arus listrik ini karena tidak memiliki kawat berduri listrik.

c. Dalam dunia pendidikan

Dalam dunia pendidikan, seperti yang telah terjadi di MAN 2 Tulungagung, literasi digital sudah merupakan bagian integral dalam setiap pembelajaran. Mayoritas guru di sekolah tersebut sudah menggunakan digital saat menyampaikan materi kepada siswa. Misalnya dalam pembelajaran qira’ah, guru menggunakan naskah teks yang diambil dari salah satu koran berbahasa Arab yang didownload dari smartphone setiap siswa sehingga menimbulkan berbagai ragam teks yang dapat diolah masing-masing siswa dengan qira'ah yang beraneka ragam.

\section{E. Penutup}

Karakteristik qira'ah dalam era literasi digital adalah dapat dilihat dari segi sifatnya yaitu merupakan proses reseptif. Qira'ah memiliki karakter konsumtif atau menerima (reseptive skill). Dia kebalikan dari kitabah (menulis) yang memiliki karakter produktif (productive skill). Qira'ah memiliki kesamaan dengan istima' sebagai keterampilan reseptif. Sedangkan fungsi qira'ah adalah penulis meringkas menjadi 
semula qira'ah sebagai tujuan (dalam artian pelafalan), kemudian bertambah untuk pemahaman, lalu penjiwaan dan terakhir adalah aplikasi dalam kehidupan seharihari.

Sedangkan fungsi qira'ah dalam era literasi digital adalah bahwa dunia sekarang adalah dunia literasi. Dunia membaca dan menulis. Dua hal ini merupakan cermin dari perkembangan peradaban dunia. Bahkan dapat dikatakan kemajuan suatu negara dapat diukur dari seberapa tinggi kualitas literasi masyarakatnya. Apalagi sekarang diiringi dengan teknologi modern dan alat-alat komunikasi yang canggih. Dunia seakan dalam genggaman. Maka qira'ah khususnya bahasa Arab harus semakin ditingkatkan, karena orientasi bahasa Arab semakin meluas. Tidak hanya untuk religius tetapi juga akademis, profesional/ praktis, ekonomis dan ideologis.

\section{DAFTAR PUSTAKA}

Al-Hadidiy, Ali. t.t. Musykilat Ta'liim al-Lughah al-Arabiyyah li ghairil 'Arab. Kairo. Dar al-Katib al-Arab

Al-Khuuli, Muhammad Ali. 1982. Asalibu Tadrisi Al-Lughah Al-Arabiyyah. Riyadl. AlMamlakah Al-'Arabiyyah As-Su’udiyyah

Azies, Furqanul dan A. Chaidar al-Wasilah. 1996. Pengajaran Bahasa Komunikatif: Teori dan Praktik. Bandung. Rosdakarya

Effendy, Ahmad Fuad. 2005. Metodologi Pengajaran Bahasa Arab. Malang. Misykat

Faruq, Umar. vol. 2. “Tathbiq Thariqah al-Qira'ah al-Muatsafah fi Ta'liim anNushush al-Adabiyyah (bit Tathbiq 'ala Thalabah Jami'ah Kediri al-Islamiyyah al-Hukumiyyah)” dalam jurnal at-Tadris. Tulungagung. IAIN Tulungagung

Hadi Masruri, Muhammad. 2006. Al-Hujum Majallat Arabiyyah 'Amaliyyah lial-Tsaqafah al-Islamiyyah. Malang. Jami’ah Islamiyyah Malang

Hermawan, Acep. 2011. Metodolgi Pembelajaran Bahasa Arab. Bandung. Remaja Rosdakarya

Husain, Thaha Ali dan Sa'ad Abdul Karim al-Waili. 2014. Ittajahaat Hadiitsah fi Tadris al-Lughah al-Arabiyyah. Yordania. Jidar lilkutub al-Alamy

Ibrahim, Abdul Alim. 1968. Al-Muwajjih Al-Fannyli Mudarrisiy Al-Lughah Al-Arabiyyah. Kairo. Dar Al-Ma'arif

Izzan, Ahmad. 2009. Metodolgi Pembelajaran Bahasa Arab. Bandung. Humaniora

Malibary, A. Akrom, dkk. 1976. Pedoman Pengajaran Bahasa Arab pada Perguruan Tinggi Agama/ IAIN. Jakarta. Depag RI 
El-Tsaqafah: Jurnal Jurusan PBA, Vol. 18, No.2, Desember 2019

Mujib, Fathul dan Nailur Rahmawati. 2012. PermainanEdukatif Pendukung Pembelajaran Bahasa Arab. Yogyakarta. Diva Press

Mustofa, Syaiful. 2011. Strategi Pembelajaran Bahasa Arab Inovatif. Malang. UIN Maliki Press

Mustofa, Bisri dan Abdul Hamid. 2011. Metode \& Strategi Pembelajaran Bahasa Arab. Malang. UIN Maliki Press

Nuha, Ulin. 2016. Ragam Metodologi \& Media Pembelajaran Bahasa Arab. Yogyakarta. Diva Press

Nurhayati, Anin. 2006. Diktat Metodologi Pengajaran Bahasa Arab. Tulungagung. STAIN Tulungagung

Sunendar, Iskandarwassid dan Dadang. 2008. Strategi Pembelajaran Bahasa. Bandung. Remaja Rosdakarya

Syahatah, Hasan. 1991. Ta'lim al-Lughah al-Arabiyah Baina an-Nadzariyah wa atTathbiq. Mesir. ad-Dar al-Mishriyah al-Libananiyah

Tarigan, Henri Guntur, 1994. Membaca sebagai Suatu Keterampilan Berbahasa. Bandung. Angkasa

Thu'aimah, Rusydi Ahmad. 2004, al-Maharaat al-Lughawiyyah Mustawiyatuha. Kairo. Dar al-Fikr al-Arabiy

Thu'aimah, Rusydi Ahmad. 1989. Ta'lim Al-Arabiyya Lighairi Al-Nathiqi biha: Manahijuhu wa Asalibuhu. Mesir. TP

Yunus, Fatha Ali dkk. 1981. Asaasiyaat Ta'liim al-Lughah al-'Arabiyyah wa at-Tarbiyah ad-Diniyah. Kairo. Dar an-Naqah

Zulhannan. 2014. Teknik Pembelajaran Bahasa Arab Interaktif. Jakarta. Rajagrafindo Persada 